\title{
The Influence of Lesson Study Strategy on Teachers's Pedagogical Quality in All State Madrasah Aliyah of Medan
}

\author{
Indra Prasetia ${ }^{1}$, Akrim $^{2}$, Sulhati ${ }^{3}$, Burhanuddin ${ }^{4}$ \\ ${ }^{1,2,3}$ Universitas Muhammadiyah Sumatera Utara, Indonesia \\ ${ }^{4}$ Madrasah Aliyah Negeri Deli Serdang, Indonesia \\ indraprasetia@umsu.ac.id
}

\begin{abstract}
The purpose of this study were : (1) to learn pedagogical strategies teachers who follow the guidance of teacher with lesson study and coaching strategies with MGMP convensional teacher, (2) to determine the interaction between teacher coaching strategies with lesson study and strategies with teacher guidance MGMP conventional and subjects the teachers' pedagogic competence, (3) to find pedagogical english teacher who followed a strategy with teacher guidance conventional MGMP, (4) to learn pedagogical math teacher who followed a strategy of coaching teachers with pedagogical lesson study and mathematics teachers who follow the strategy with teacher guidance conventional MGMP. This study is quasi-experimental research. The number of samples were 60 teachers. The tecnique of determining the sample is done by random sampling. Research hypptheses were tested using Anova 2 ways used before Anova first tested the data analysis requirements of the test for normality of data using Lillieofors test, and homogeneity of variance using the test Bartlet.
\end{abstract}

Keywords

pedagogic competency, teacher subject; lesson study

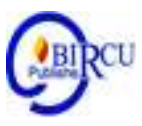

\section{Introduction}

Education is one of the necessities of life. Education play useful role to develop self potential of the student so that they have the spiritual power of religious, self-control, personality, intelligence, moral dignity, as well as the skill that necessary for her, society, nation and country. Ki Hajar Dewantara in Rivai and Murni (2009) define education as the guide to all the forces of nature that exist in a child so that later they can be human and the member of society that can achieve the salvation and happiness as high as possible. Simply, the problem of education can be divided by two, which is systematic and non systematic problems. The systematic problem is the problem that related to the system and is happening almost everywhere that education system goes, like grading and academic curriculum. And the non-systemic problem is an unrelated with the system and only occur in narrow areas like school culture and parental participation.

According to the Jakarta post appeared on the headline newsof the December 09 2010, a report published by Sagala (2007), still low level of education through surveys program for International Student Assessment (PISA) Indonesia was in the eighth rank from below both in 2006 and in 2009 as compared with the countries neighbor that still only in one region. This is a big question as why the quality of education in the motherland is so low. Prasetia (2016) governments are realizing the importance of the role a teacher plays in his or her profession, then some laws are published, including those of teachers and professors mentioned in this law. Teachers are professional educators with the primary task of educating, teaching, guiding, directing, training, assessing and evaluating learners 
for early childhood formal education, primary education and secondary education. And then the government continue on giving motivation for teachers launching profession allowance for teachers who pass for certification testing beginning in 2006. But refers to the PISA's result that have describe above, it seems to me that the professional predicate of a teacher whether who has been through certification test or who has not yet questioned as a holder of a role in the education process.

The government, through the national department of education that collaborated with Japan International Cooperation Agency (JICA) in 2009 retry to make improvements in adoption for that began in Japan since 1870 as a lesson study. A lesson study is a method of analysis of cases in learning practice, intended to help teacher pedagogical development and open up opportunities for them to learn from each other based on actual practices at the class level. Lesson study is divided into three sections: planning (plan), preparation and observation (do) and reflection.

This study leads to challenges faced with all elements so that obtain a teacher training formula in effective and efficient positions that create the standard teacher improvement that is expected in the development of professional competence. MGMP comparisons are offered so that be able to give wise and appropriate solution for improving education quality in facing the issues of micro and macro learning. English subjects have different characteristics from match. Of course, with these different characteristics the teacher who studied the subjects will also be characteristically different, this is where the researchers are interested in examining which MGMP is properly used to improve the pedagogic competency to the two different subjects teacher above.

\section{Review of Literatures}

Government through the national department of education that cooperated with Japan International Cooperation Agency (JICA) in 2009 tried to improve in adopting a system that had started in Japan since 1870 as a lesson study. Friedman (2005) the lesson study is a method of analysis of cases with learning practices, referred to helping teachers' professional development and opening up opportunities for them to learn from real practices at the class level.

In its application this MGMP lesson study strategy applies to three parts: plan, action and observation (Do) and reflection (See). In the planning department, whether a person or a group of teachers makes a learning plan. One teacher conducts a study based on a planned plan and his colleagues observe the learning, and they reflect on the shared learning. Lewis (2002) mentions 3 (three) the stage of activity is planning, implementing (do) study and observation and reflection, details of the three stages as follows:

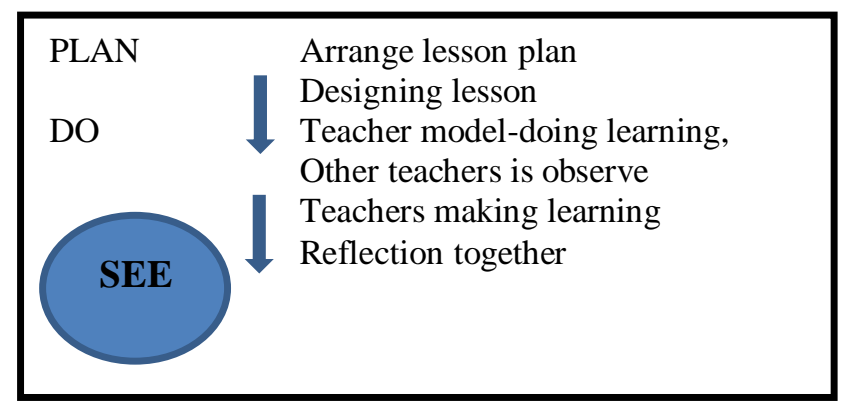

Figure 1. Lesson Plan 
The deliberation in the MGMP is an excellent value in the philosophy of the state in pancasila is also in religious values. As stated in the Koran in Surah Ali Imran 159 meaning: Ten by the grace of God that you deal with them with kindness. If you ever become hardhearted again, they will likely distance themselves from your surroundings. Therefore appeal to them, plead for forgiveness, and confer with them on such matters (other worldly matters such as education, economics, and so on). Then when you've made up your mind, then put your trust in god. Surely god loves those who put their time before him.

In a universally universal sense is defined as "mastery or acquisition of knowledge of a subject ora learning skill, experience, or instruction" a psychology of education defines more tightly as "a change in a person caused by experience". Similarly with teaching can be defined as showing or helping a person learn how to do something, give instruction, guide in the study of something, prepare knowledge, make known or understand.

According to Ibnu Miskawaih in his book Tahzib Al-Achlaq, say, learning is one of the processes of gaining knowledge, knowledge is one of the ways to acquire truth. While truth is an assertion without doubt, it begins with an attitude of doubt first.

MGMP is a professional training for teachers of subjects in educational force. According to his name, the teacher's deliberation, MGMP's strategy is a contest for the teacher's subject to deliberation. Through this MGMP strategy activity, the teacher's subjects can sit together to break down the issues faced in pursuing professional assignments every day. Through MGMP, teachers can share in addressing the current government policies in improving learning efforts. The conventional MGMP strategy is the teacher's activities that have been conducted through many regions with principles based on classifying, visualizing, developmental problems, discussions. Here is a scheme about conventional wisdom.

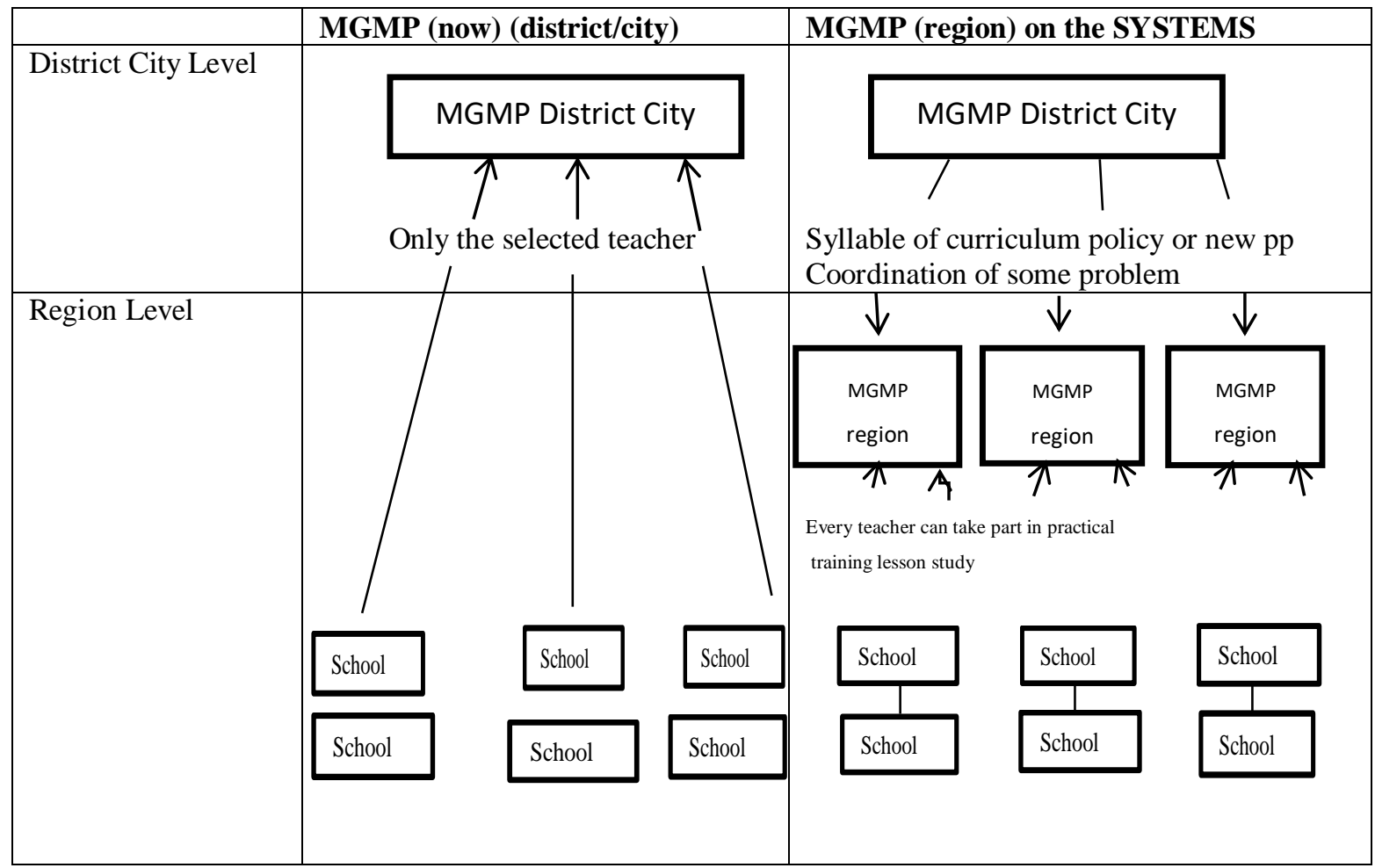

Figure 2. MGMP Today in District or City (Source: Diknas, 2007) 
The word competency comes from the English language, competence, meaning "competence, ability, authority". In the big dictionary of Indonesian, competence requires the authority to determine (decide something). Competent means competent people, authority and authority (deciding, determining, and deciding) things. Whereas, according to government regulation number 100 year 2000, competence is the ability and characteristics of a civil servant of the knowledge, skills and behavior necessary in the on the performance of his office duties. Manopo (2011) explained competence is part of a relatively stable individual personality, and can be seen and measured by the behavior of the individual, at work as well as in various situations. The competence of a person indicates a capable measure of conduct in various situations that is consistent enough for a considerable period of time, and not merely coincident. Prasetia, et al (2020) competencies have predictive requirements that prove empirical to be the cause of his next success.

Directorate of Basic and Middle Education (2007) a "blue pocket book" on "ten teacher competency" which is: (a) having the personality of a teacher, (b) having mastered the foundation of instruction, (c) having a teaching program, (e) performing the teaching process, (f) administering the education assessment, (g) administering instruction, (h) administering the school administration, (i) obtaining cooperation and interactions with a peer and community teacher, (j) enduring a simple research. The term teacher competency holds a lot of meaning, as did broke and stone 1995 in his book Mulyasa (2011) explain that teacher competency as i descriptive of qualitative nature of teacher behavior appear to be entirely meaningful. Teacher competence is a qualitative representation of the substance of meaningful teacher's behavior meanwhile, in his work an Indonesian education expert $\mathrm{Ki}$ Hajar Dewantara writes that a teacher functions in its job as suri tauladan, motivator and director, giving instruction, guiding in studies, preparing for educational knowledge more familiar: ing madyo mangun karso, ing so sung tulodo, tut wuri handayani. This is a teacher's requirement to exercise competence in the performance of his or her duties as a professional. Diknas (2007) as for the basic foundation of teacher conferences is by law, among others: (a) laws number 20 years 2003 about the national education system, (b) laws number 14 of 2005 about teacher and teacher states a teacher/professor has four competencies namely pedagogical competence, personality competency, social competence, professional competence. In line with that then formal teachers and professors became professions.

Teacher performance is the implementation of a plan that has been prepared through planning good learning activities that is by completing learning tools in the form of syllabus and learning implementation plans (RPP) instead planning poor learning activities if the teacher does not prepare learning tools in the form of syllabus and lesson plans. Implementation of performance is carried out by human resources who have the ability, competence, motivation, and interests (Saragih and Ananda, 2019).

Like those cited by Mulyasa (2007) terms education with pedagogical, whereas education is called pedagogical. Education is emphasized more in this regard in practice, particularly as it relates to learning activities. The beaver at this terminology is difficult to separate between pedagogical science and pedagogical education because the two must be conducted side by side, reinforcing one another in improving the quality and purpose of education.

Diknas (2007) in the national education policy, government has set forth four types of teacher competence as defined by the definition of government regulation no. 19, 2005, regarding the national standard of education. In this study, under the definition of teacher pedagogical competence, then explain in the rules: pedagogical competencies that include skills in learners' management: (a) insight into or educational attainment; (b) insight into 
learners; (c) curriculum planes/syllabus; (d) design learning; (e) dialogue and educational implementation of learning; (f) study result evaluation ; And (g) educational development to actualize its various potential.

Learning a second language is a long and complex process, so much of the influence to achieve communication mastery skills in addition to the first language and to achieve a new language, a new culture, a new way of thinking, feeling, and acting. Total commitment, total engagement, total physical, intellectual, and emotional responses total is needed to the success of sending and receiving messages in a second language. Many variables are involved in language mastery processes. Having studied language is not just a set of simple steps that you can program in a briefing. So many problems exist that foreign-language courses often become an inadequate field of training for the success of learning a second language. Only a few people, who can achieve foreign-language eloquence through within the confines of a classroom.

Sumardi (2009) the purpose English education for talent student as follow. (a) emphasis on the high-thinking process (critical thinking, inference, analysis, synthesis, evaluation; (b) emphasis on creativity, among other things in reading and creative expression, (c) classic literacy mastery, includes form and content; (d) the emphasis on the production of oral writing and work (unwritten) for the great audience, (e) telecoping basic skills in paramasastra and pointing.

Math is the study of logic regarding form, structure, mass and other interrelated concepts with a large number that divides into three areas of algebra, analysis, and goemetry. Smith \& Ragan (2005) states that mathematics is a people mindset which the truth is general (deductive). Match truth is ultimately coherent. In the scientific world, there are three types of truth known as: 1) coherence, or consistency, truth, based on truth received accordingly; 2) correlated truth, that is, truth based ona compatible reality or reality; 3) pragmatic truth which isthe truth that is based on benefits or purposes.

Above has also been briefly explained on the minister's regulation of teacher competency in the 16th minister's rule of 2007. Then the explanation on the following sheet the rule describes the additional teacher competence specifically by the teacher in math subjects as follows: (a) using compound numbers, relationships between numbers, various number systems and number theories, (b) using measuring (c) using match's logic, (d) using geometric concepts, (e) using statistical concepts and opportunities, (f) using patterns and functions, (g) using algebraic concepts (h) using geometric concepts and calculus, (i) using discrete mathematical concepts and processes, (j) using trigonometric concepts, (k) using vectors and matrices, (l) explaining match's history and philosophy, (m) being able to use props, gauze, calculating equipment, computer software, mathematical models, and statistical models.

Everard, et al (2004) arguing hat knowledge based on teacher insight as a researcher whose problems and processes are rooted in the practice of the class. Teacher research can refer to premeditated activity instead of spontaneous inquiry, which is done systematically and intensive inquiry. Notes that this world has seen a rapid rate of development for the professional teacher development area in the last two decades where four stages like the one presented on table 1: 
Table 1. The professional teacher development area in the last two decades

\begin{tabular}{|c|c|l|}
\hline Years & Activities & \multicolumn{1}{|c|}{ Explanation } \\
\hline $1950-1960$ & Training & $\begin{array}{l}\text { Centered on the process hoe to } \\
\text { teach the new syllabus }\end{array}$ \\
\hline $1970-1980$ & Brief Course & \\
\hline $1980-1990$ & Professional Development & $\begin{array}{l}\text { Thorough approach when } \\
\text { students are on vocation }\end{array}$ \\
\hline 1990-sekarang & Learning and Developing & $\begin{array}{l}\text { Using culture approach, school } \\
\text { and teacher make own choice } \\
\text { based on the priority }\end{array}$ \\
\hline
\end{tabular}

Based on the theoretical studies and theoretical framework already outlined above, then the research hypothesis can be formulated as follows:

1. Pedagogic competencies of teachers who follow the lesson study higher than the pedagogical competencies of teachers who follow MGMP conventional.

2. There are influences between MGMP interactions with teacher pedagogical competencies.

3. Pedagogic competencies of an English teacher who attends a lesson study higher than conventional pedagogical competencies following conventional MGMP.

4. Pedagogical competencies of mate match's teacher who follows the lesson study is lower than pedagogical competencies of a math teacher who

\section{Research Methods}

This study is conducted in senior high school (State Madrasah Aliyah 1 and State Madrasah Aliyah 3), and private Madrasah (KKM) Teamwork. The subject of research is a teacher affiliated with MGMP MAN 1 and his KKM and MAN 3 and his KKM in Medan City. This research use experimental quasi methods with $2 \times 2$ factorial designs. Used experimental quasi methods because control of subjects under investigation was very limited. Other variables that are thought to affect variables (Sudjana, 2005 \& Sugiyono, 2008).

Table 2. Research Desian

\begin{tabular}{|l|c|c|}
\hline (A) & $\begin{array}{c}\text { Teacher Coaching } \\
\text { Strategies With Lesson } \\
\text { Study (A1) }\end{array}$ & $\begin{array}{c}\text { Teacher coaching strategies } \\
\text { with conventional MGMP } \\
\text { (A2) }\end{array}$ \\
\hline Attribute variable (B) & $\mathrm{Y}(\mathrm{A} 1 \mathrm{~B} 1)$ & $\mathrm{Y}(\mathrm{A} 2 \mathrm{~B} 1)$ \\
\hline English Teacher (B1) & $\mathrm{Y}(\mathrm{A} 1 \mathrm{~B} 2)$ & $\mathrm{Y}(\mathrm{A} 2 \mathrm{~B} 2)$ \\
\hline Mathematic Teacher (B2) & & \\
\hline
\end{tabular}

Explanation :

A : Model MGMP

B : Subject teachers

A1 : Pedagogical competence of teachers who use the MGMP lesson study strategy

A2 : Pedagogical competence of teachers who Use the MGMP convensional strategy

B1 : English subject teacher

B2 : Mathematic subject teacher

A1B1 : Teachers who use the MGMP lesson study strategy in English subjects 
A1B2 : Teachers who Use the MGMP lesson study strategy in mathematic subjects

A2B1 : Teachers who use conventional MGMP strategies in English subjects

A2B2 : Teachers who use conventional MGMP Strategies in mathematic subjects

Y : Pedagogical competence

The dependent variable in this study is the teacher's pedagogical competence, while the independent variable is coaching in the form of conventional strategies and lesson study strategies. The attribute independent variable is subjects consisting of subjects in English and mathematics.

The target population of this study were all Madrasah Aliyah teachers throughout the city of Medan. While the outreach population is 85 teachers who are members of the mathematics MGMP strategy. The largest population of MAN 1 Medan and MAN 3 Medan and Madrasah Aliyah Private in KKM MAN 1 Medan and all KKM MAN 3 Medan. The sample selection was carried out by means of random sample sampling, then the composition of the sample members for each treatment consisted of 15 teachers.

To obtain data from the results of this study needed an instrument to measure the pedagogical competence of teachers using the PGB test and questioner. To measure the pedagogical competence of subject teachers, it is developed based on the rules set by the measuring instrument used in ministerial regulations. As for the measuring instrument used to explain the results of pedagogical competence is a form of multiple-choice questions and questioner questions each of 40 test questions and 14 questioner statements.

\section{Results and Discussion}

\subsection{Description of Data: Testing Data Analysis Requirements}

Table 3. Test english and mathematics teacher's pedagogical ability

\begin{tabular}{|l|c|c|c|}
\hline \multicolumn{1}{|c|}{ Sample group } & Lilliefors count & dk & Lilliefors table $(\mathbf{a}=\mathbf{0 , 0 5})$ \\
\hline English teacher & 0,139 & 30 & 0,162 \\
\hline Mathematic teacher & 0,101 & 30 & 0,162 \\
\hline Sample group & Lilliefors count & $\mathbf{d k}$ & Lilliefors table $(\mathbf{a}=\mathbf{0 , 0 5})$ \\
\hline Lesson Study & 0,154 & 30 & 0,162 \\
\hline Conventional & 0,109 & 30 & 0,162 \\
\hline
\end{tabular}

Pedagogical competency Table 4 test for teachers treated with coaching strategies with lesson study and coaching strategies with MGMP conventional.

Table 4. Teachers Treated with Coaching Strategies with Lesson Study and Coaching Strategies with MGMP Conventional

\begin{tabular}{|c|c|c|c|}
\hline Sample group & Lilliefors count & $\mathbf{d k}$ & Lilliefors table $(\mathbf{a}=\mathbf{0 , 0 5})$ \\
\hline Bl-LS & 0,121 & 15 & 0,229 \\
\hline BI-K & 0,103 & 15 & 0,229 \\
\hline MM-LS & 0,109 & 15 & 0,229 \\
\hline MM-K & 0,177 & 15 & 0.229 \\
\hline
\end{tabular}

The summary table 5 of variance homogeneity test results between sample groups of pedagogic competence of english and mathematics teachers with the $\mathrm{F}$ test at the level of significance $=0.05$. 
Table 5. Table of Variance Homogeneity Test

\begin{tabular}{|c|c|c|c|c|}
\hline Sample & Varians & F $_{\text {count }}$ & $\mathbf{F}_{\text {table }}$ & Conclusion \\
\cline { 1 - 2 } English & $\mathrm{S}^{2}=8,21$ & & & \multirow{2}{*}{1,53} \\
Mathematic & $\mathrm{S}^{2}=5,35$ & 1,86 & Homogen \\
\hline
\end{tabular}

Summary Table 6 test results of homogeneity of variance between groups sample pedagogical competencies of teachers who are treated teacher coaching strategies with lesson study and teacher coaching strategies with conventional MGMP with the F test at the significance level $a=0.05$.

Table 6. Table of Variance Homogeneity Test

\begin{tabular}{|c|c|c|c|c|}
\hline Sample & Varians & $\mathbf{F}_{\text {count }}$ & $\mathbf{F}_{\text {table }}$ & Conclusion \\
\hline Lesson study & $\mathrm{S}^{2}=12,18$ & & & \\
\cline { 1 - 2 } Conventional & $\mathrm{S}^{2}=7,65$ & 1,59 & 1,86 & Homogen \\
\hline
\end{tabular}

Summary Table 7 test results of homogeneity of variance between groups the Bartlet Test sample at a significance level $a=0.05$

Table 7. Test Results of Homogeneity of Variance

\begin{tabular}{|c|c|c|c|c|}
\hline Sample & Varians & $\mathbf{F}_{\text {count }}$ & $\mathbf{F}_{\text {table }}$ & Conclusion \\
\hline $\mathrm{B} 1-\mathrm{LS}$ & $\mathrm{S}_{1}{ }^{2}=5,09$ & & & \multirow{2}{*}{1,59} \\
\cline { 1 - 2 } $\mathrm{BI}-\mathrm{K}$ & $\mathrm{S}_{2}{ }^{2}=3,65$ & & 1,86 & \\
\cline { 1 - 2 } MM-LS & $\mathrm{S}_{3}{ }^{2}=5,21$ & & & \\
\hline MM-K & $\mathrm{S}_{4}{ }^{2}=4,85$ & & & \\
\hline
\end{tabular}

Summary Table 8 results of the treatment of pedagogical competencies of English teachers and mathematics teachers who follow lesson study and teacher coaching ttrategies with conventional MGMP.

Table 8 .Results of the Treatment

\begin{tabular}{|c|c|c|c|c|c|c|}
\hline $\begin{array}{l}\text { Coaching } \\
\text { strategy }\end{array}$ & \multicolumn{2}{|c|}{ Lesson Study } & \multicolumn{2}{|c|}{$\begin{array}{c}\text { MGMP } \\
\text { Conventional }\end{array}$} & \multicolumn{2}{|c|}{ Total } \\
\hline \multirow{3}{*}{ English } & $\Gamma_{-}$ & 39000 & $\Gamma=$ & 32100 & $\Gamma=$ & 7110 \\
\hline & $\overline{\bar{X}}$ & 26,00 & $\bar{X}$ & 21,40 & $\bar{X}$ & 23,70 \\
\hline & $X_{11}=$ & 20,00 & $X_{21}=$ & 2,1 & $\begin{array}{ll}X \\
1 .=\end{array}$ & 20 \\
\hline \multirow{4}{*}{ Mathematic } & $\Gamma=$ & 20100 & $\frac{1121=}{\Gamma-}$ & $\frac{15}{307}$ & $\frac{11=}{\Gamma-}$ & $\frac{30}{586}$ \\
\hline & $2=$ & 201,00 & $2-$ & & $2-$ & 500 \\
\hline & $\bar{X}_{12}=$ & 18,73 & $\bar{X}_{22}=$ & 20,50 & $\bar{X}_{2 .}=$ & 19,53 \\
\hline & $\mathrm{n}_{12}=$ & 15 & $\mathrm{n}_{22}=$ & 15 & $\mathrm{n}=$ & 30 \\
\hline \multirow{3}{*}{ Total } & $\Sigma=$ & 671,00 & $\Sigma=$ & 628,00 & $\Sigma=$ & 1299,00 \\
\hline & $\bar{X}_{.1}$ & 22,37 & $\bar{X}_{.2}=$ & 20,93 & $\bar{X}_{. .}=$ & 21,65 \\
\hline & $\mathrm{n}=$ & 30 & $\mathrm{n}=$ & 30 & $\mathrm{n}=$ & 60 \\
\hline
\end{tabular}




\subsection{Hypotesis}

1. Hypothesis testing differences in strategies for teacher development with lesson study and teacher development strategies with conventional MGMP on teacher pedagogical competence.

Based on the summary of the calculation results in accordance with table 4.16 above, it can be seen that the value of $F_{\text {count }}=6.51$. For the value of the distribution of $F$ with $\mathrm{dk}$ (1.59) at $\mathrm{a}=0.05$ is $\mathrm{F}_{0,05(1.59)}=4.11$. These results indicate that $\mathrm{F}_{\text {count }}>\mathrm{F}_{\text {table, }}$ so as to give a decision to reject Ho at the level of syndication $a=0.05$, then the research hypothesis is accepted competency. The average pedagogical competence of teachers who followed the teacher coaching strategy with lesson study 22.30 while the average pedagogical competency of teachers who followed the conventional teacher coaching strategy was 20,93. So that, the pedagogical competence of teachers who take the conventional MGMP.

2. Hypothesis testing of the interaction between teacher coaching strategies with lesson study and teacher coaching strategies with conventional MGMP with subjects to teacher pedagogical competencies.

Based on a summary of the calculation results in accordance with the table above, it can be seen that the value of the value of $F_{\text {count }}=36.45$. For the value of the distribution of $\mathrm{F}$ with $\mathrm{dk}(1.59)$ at $\mathrm{a}=0.05$ is $\mathrm{F}_{0,05}(1,59)=4.11$. These results indicate that $\mathrm{F}_{\text {count }}>\mathrm{F}_{\text {table, }}$ thus giving a decision to reject Ho at a significance level of $\mathrm{a}=0.05$, the research hypothesis which states "There is an interaction between teacher coaching strategies with lesson study and teacher coaching strategies with conventional MGMP and subjects towards teacher pedagogical competence subjects in MAN Medan, " This is proven true.

3. Hypothesis testing of differences in teacher coaching strategies with lesson study and teacher coaching strategies with conventional MGMP on English teacher pedagogical competence.

The results of calculations using the Tuckey Test show $\mathrm{Q}_{\text {count }}=8.59$. For the studentized range critical value with $\mathrm{dk}(3.56)$ at $\mathrm{a}=0.05$ is $\mathrm{F}_{0.05}(3.56)=3.40$. These results indicate that $\mathrm{Q}_{\text {count }}>\mathrm{Q}_{\text {table, }}$ thus giving a decision to reject Ho at a significance level of $\mathrm{a}=$ 0,05 , the research hypothesis is accepted. the average pedagogical competence of english teachers who follow teacher training with lesson study 26,00 while the average pedagogical competency of english teachers who follow teacher development strategies with conventional MGMP 21.40. So, it appears that the pedagogical competence of English teachers who follow the teacher training strategy with lesson study is higher than the english teacher's pedagogical competency who follows the teacher development strategy with conventional MGMP.

4. Hypothesis testing of differences in teacher coaching strategies with lesson study and teacher coaching strategies with conventional MGMP on mathematics teacher pedagogical competence

The results of calculations using the Tukcey Test showed $\mathrm{Q}_{\text {count }}=3.55$. For the critical value of the studentized range distribution with $\mathrm{dk}(3.56)$ at $\mathrm{a}=0.05$ is $\mathrm{F}_{0,05}(3.56)=$ 3.40 this results $\mathrm{Ho}$ at the significance level $\mathrm{a}=0.05$ then the hypothesis is accepted. So that it is obtained that the mathematics teacher's pedagogical competency who follows the teacher coaching strategy with lesson study is lower than the mathematics teacher's pedagogical competency that follows the conventional teacher coaching strategy. 


\section{Conclusion}

The method used in this study is a quasi-experimental method, the independent variable is the utilization of teacher coaching strategies divided into two namely teacher coaching strategy with lesson study and teacher's coaching strategy with conventional MGMP. While the dependent variable is pedagogical competence in the type of subject that is shared with english and mathematics subject teachers. This research was conducted to English language teachers and mathematics teachers at Madrasah Aliyah Medan City in 2020 academic year. From the data obtained in the field, the results of hypotheses and discussion of research results and data analysis, researchers can draw several conclusions as follows:

1. Overall in this study the pedagogical competence of teachers who follow the teacher coaching strategy with lesson study is higher than the pedagogical competence of teachers who follow the strategy of teacher development with conventional MGMP.

2. From this study found the effect of interaction between teacher coaching strategies with lesson study and teacher coaching strategies with conventional MGMP and on subjects towards teacher pedagogical competence in MAN Medan City.

3. It can be seen that the English teacher's pedagogical competency who follows the teacher coaching strategy with lesson study is higher than the English teacher's pedagogical competency who follows the teacher development strategy with the conventional MGMP.

4. The pedagogical competence of mathematics teachers who follow teacher coaching strategies with lesson study is lower than the pedagogical competencies of mathematics teachers who follow teacher coaching strategies with conventional MGMP.

\section{Implication}

1. Implications for teachers in improving pedagogical competence as one of the competencies that subject teachers must possess

MGMP has an influence to improve pedagogical competencies of lesson study and improve pedagogical competence of English teachers so steps need to be taken so that english teachers understand the implementation of teacher coaching strategies with lesson study continuously applied such as training, workshops and seminars. Efforts to improve teacher competency consisting of four competencies, one of which is pedagogical competence, is needed strategies such as MGMP implementation. MGMP needs to be carried out continuously and tight supervision so that Indonesian teachers who improve their teaching abilities so that students feel learning is meaningful and meaningful. Teachers are challenged to be able to innovate in the learning process so that teachers who have not done so can realize that in the future learning problems will be more complex, with the subject teachers' conference (MGMP) will be able to move or generate enthusiasm to compete while solving problems in learning.

2. Implications for madrasas in the ministry of religion and the ministry of national education

As an institution managing madrasah education, the ministry of religion, the ministry of national education has a strategic role in improving the quality of education which is much needed commitment to improve the quality of teachers who carry out the education process for the community and the learning process in Madrasah. In connection with the above mentioned matter, it is necessary to make a breakthrough in coaching teachers, one of which is to apply MGMP as a place for teachers to overcome problems 
that might be encountered in the learning process. Forming a team to design a strategy especially lesson study is a must because it has been proven that the teacher coaching strategy with lesson study can improve teacher's pedagogical competence. The ministry of religion and the ministry of culture and dam should provide the budget and facilities so that the MGMP program runs well and smoothly.

\section{References}

Akrim, Zainal, A, and Munawir. (2016). M-97 Developing Model and Textbook Integrated to Spiritual and Social Competence of Math Subject for Grade VII in State Junior High School of Medan. International Conference on Mathematics, 2016.

Everard, K.B, Morris, G, Wilson, 1. (2004). Effective School Management, London: Paul Chapman Publishing.

Directorate of National Education. (2007). Cultural Development and Learning Climate in Schools (training material for competency development of prospective school principals / principals). Ministry of Education. Jakarta

Friedman, E. R. (2005). An Examination of Lesson Study as a Teaching Tool in U.S. Public Schools, Desentation, Ashland OH: Ashland University.

Lewis, C. (2002). Lesson study: A handbook of teacher-led instructional change. Philadelphia: Research for Better Schools.

Manopo, C. (2010). Competency Based Talent and Performance Management System. Jakarta. Salemba Empat.

Mulyasa, E. (2011). Character Education Management. Jakarta: Earth Literacy.

Mulyasa, E. (2007). Teacher competency standards and certification. Bandung: Youth Rosdakarya

Prasetia, I. Research Methodology. Faculty of Teacher Training and Education, UMSU

Prasetia, I. Analysis of the Effectiveness of Schools (a Study at State Junior High Schools in Medan, Indonesia). Journal of Humanities and Social Science (IOSR-JHSS) Volume 21, Issue 8, Ver. 10 (Aug. 2016).

Prasetia, I. Lecturer Competency Development Model in Designing a Line Learning Resources in University of Muhammadiyah Sumatera Utara. Budapest International Research and Critics Institute-Journal (BIRCI-Journal), Volume 3, No 4, November 2020.

Prasetia. I, Akrim, and Sulasmi. E. (2020). Effective Competency Based School Model, Jurnal Tarbiyah, 27 (1), 2020.

Rivai. F, and Murni, S. (2009). Education Management. Jakarta: Rajawali Pers.

Sagala, Saiful. (2007). Strategic Management in Improving the Quality of Education. Bandung. Alfabeta.

Saragih, S.L., and Ananda, R. (2019). The Relation between the Empowerment of Teacher's Meeting and Achievement Motivation on Teacher Performances in MTsN 3 (Islamic Junior High School 3) Simalungun. Budapest International Research and Critics in Linguistics and Education (BirLE) Journal. P. 115-114.

Smith, P.L, Ragan, T.J (2005). Instructional Design. NJ: John Wiley \& Sons, Inc, River Street, Hoboken.

Sudjana. (2005). Statistical Methods. Bandung. Tarsito

Sugiyono. (2008). Educational Research Methods, Quantitative Approaches. Qualitative and R\&D. Bandung: Alfabeta.

Sumardi. (2009). The Effectiveness of the English MGMP Revitalization Program as a Media for fostering Teacher Professionalism. Thesis, Yogyakarta: Yogyakarta State University. 